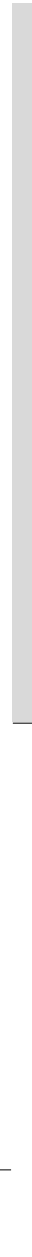

\title{
HAプロセスを利用した高強度・高鞄
}

技

Technical 資料
性金型の開発

五十川幸宏 $* 1$, 吉田広明*1，井尻裕之*2

\section{Complex Shaping Die with High Hardness and Toughness by using HA-Process}

Sachihiro Isogawa, Hiroaki Yoshida and Hiroyuki Ijiri

\section{Synopsis}

The applicability of hobbing die made by ausforming process was tested using $0.4 \mathrm{C}-1 \mathrm{Mn}-3 \mathrm{Cr}-2 \mathrm{Mo}-1 \mathrm{~V}$ hot work tool steel which had excellent thermal shock and fatigue resistance. Basic experiments on ausforming showed the increase in hardness and toughness of this steel, which was derived from the refinement of microstructure. The hot work steel die for bevel gear was hobbed in this ausforming process (HA-Process) and the longer tool life than conventional electric-discharge-machined die was achieved in
L 1.緒 $\overline{\overline{\bar{D}}}$

大量に使用する金型の製造コストを抑える手段とし て，工具類 (ペンチ , スパナなど) ，コイン , ナイフな どを鍛造する金型がホビング1)にて作られている．ホ ビングとは，Fig.1に示すように製品の形状を転写した マスターパンチを焼なましされた工具鋼に押しつけるこ とにより金型を作る方法である，一本のマスターパンチ (焼入焼戻し処理実施) にて数十個以上の金型を精密に 製造することが可能で, 切削および放電加工に比べ安価 にかつ短時間に金型が製造できるだけでなく，鍛造によ るメタルフローの連続化などにより，金型寿命の向上も 図ることができる

金型の寿命を高める手段の一つとして最適な合金設計 により高強度・高勒性の工具鋼の開発が精力的に進めら れている，しかし，熱間工具鋼を例にとると，冷間鍛造

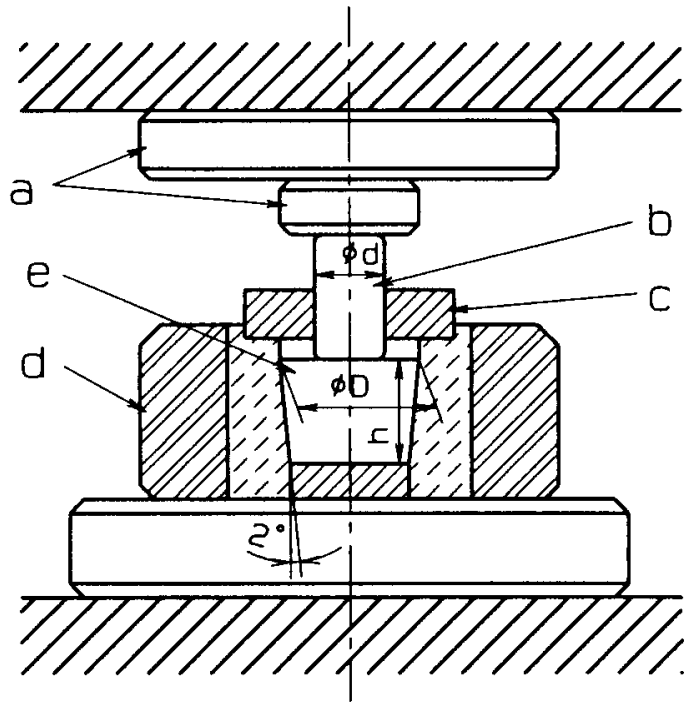
a: pressure plate
b: Master punch(die-hob)
c: centering guide
$\mathrm{d}$ : retaining ring
e: female mould

1997年3月12日受付

*1 大同特殊鋼 (株) 技術開発研究所(Research \& Development Lab., Daido Steel Co., Ltd.)，＊2 大同特殊鋼 (株) 星 崎工場(Hoshizaki Plant, Daido Steel Co., Ltd. ) 
用鋼と比較して高温において軟化抵抗や耐ヒートチェッ ク性などの熱特性に優れているが，弚の特性上比較的硬 さの低い状態で使用しており，乥れによって，型摩耗と 変形を受けやすくなる2).

一方，材料の勒性を低下させることなく強度を著しく 高めることができる加工熱処理方法の一つとしてオース フォーミングが知られている．Fig.2にオースフォーミ ングプロセスの概略を示す．材料をいったんオーステナ

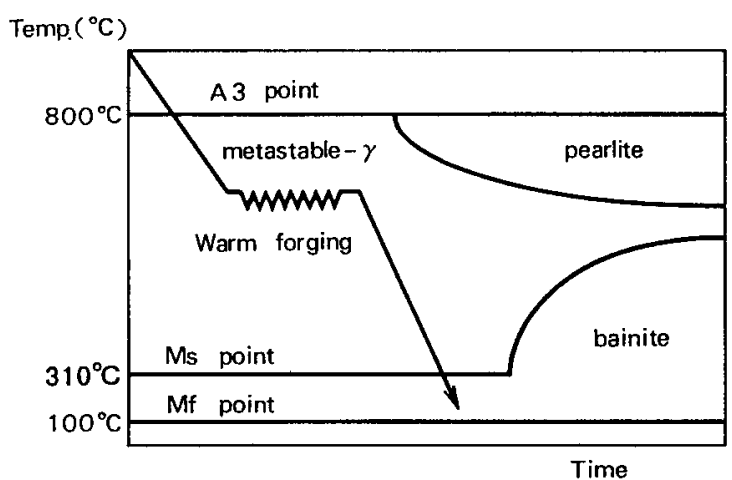

Fig. 2. Schematic illustration of ausforming.

イト化させた後降温させ,$M s$ 点以上 $A 3$ 点以下の準安定 オーステナイト中で塑性加工を行い, 弚の後焼入れる方 法で, いわば焼入れ途中に塑性加工を行うプロセスであ る.オースフォーミングの高強度化のメカニズムは, 次 のように説明できる.すなわち，加工中に導入されたセ ル状転位が無拡散変態であるマルテンサイト変態時にす べり面に対して整合性のあるものだけが主に引き継が れ，また均一に分布する。この時 $\mathrm{V}$, Moなどの強力な炭 化物生成元素が含まれているものは, 加工時に微細な加 工誘起炭化物が析出し, 転位密度がより一層高まる。ま た加工硬化組織からのマルテンサイト变態により，マル テンサイトラスは細かく分断される.しかし, 準安定才 ーステナイト中の塑性加工は, 拡散変態であるフェライ 卜変態, パーライト变態を促進し, 焼入性を阻害すると ともに,オースフォーミング時の変形抵抗は, C 含有量 と末固溶炭化物量によって支配されるために焼なまし材 を使った温間鍛造プロセスよりも变形抵抗が増加する 〜6) . オースフォーミングの工具鋼への適用に関しては， 大森ら $\left.{ }^{7} ， 8\right)$ によ古くから研究がなされている.

そこで, 本研究ではホビングとオースフォーミングを 熱間工具鋼の中でも, 高温において熱疲労特性に優れた 工具鋼として知られている3C r - 2Mo-1V系熱間工具鋼 (大同鋼種名DH71) に適用し, 強度と鞄性を兼ね備えた
金型を塑性加工により製造するHAプロセス（ Hobbing in A usforming Process）を開発し，光の基礎特性と実機に 適用した結果を紹介する．

\section{[2. 加工性試験と機械的性質 $]$}

\section{1 供試材}

供試材は3Cr-2Mo-1V系の熱間ダイス鋼で, 弚の化学 成分をTable 1 に示す．本鋼は，熱間ダイス鋼の中で硬 さ的には最大HRC53程度とやや低めであるが，軟化抵抗 が最も高い鋼種の1つである.Ms点は $310^{\circ} \mathrm{C}, \mathrm{Mf}$ 点はお

Table 1. Chemical composition of the test steel (mass

\begin{tabular}{c|c|c|c|c|c|c|c|c}
\hline Steel & $\mathrm{C}$ & $\mathrm{Si}$ & $\mathrm{Mn}$ & $\mathrm{P}$ & $\mathrm{S}$ & $\mathrm{Ni}$ & $\mathrm{Cr}$ & $\mathrm{Mo}$ \\
\hline $\mathrm{DH} 71$ & 0.35 & 0.49 & 0.96 & 0.018 & 0.04 & 0.06 & 2.93 & 0.96
\end{tabular}

よ光100Cである。

試験片は直径26mmの素材を $800^{\circ} \mathrm{C} \times 1 \mathrm{~h}$ にて球状化焼な まし処理後，切削により仕上げた．弚の寸法は前方押し 出し試験片の場合，直径を $25 \mathrm{~mm}$ とし長さを40mmとした。 変形抵抗の測定には, 日本塑性加工学会が推奖9)して いるように高さを直径の1.5倍に選び15.0× 22.5mmとし た . 素材の球状化焼なまし後の硬さはHV180〜190であ つた.

\section{2 . 2 実験方法}

変形抵抗測定試験および前方押出し試験はFig.3に示 す加熱冷却条件に従い行った .一つはオースフォーミン

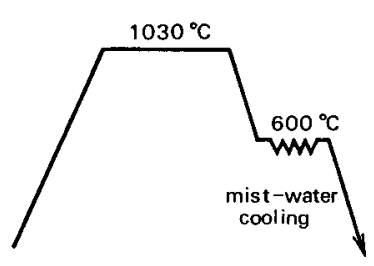

(a) HA-Process (Ausforming)

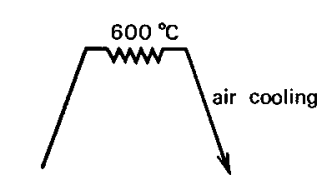

(b) Warm forging (Conventional)
Fig. 3. Heat patterns for experiment.

グプロセスであり，もう一つは通常の温間加工である 加工温度はどちらも $600^{\circ} \mathrm{C}$ を選定した . オースフォーミ

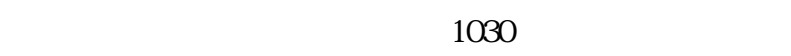
化温度に加熱保持された後, 試験温度まで空冷され試験 された．なお，試験直前の温度は放射温度計により管理 した . 有限要素法により計算した加工直前の中心と側面 中央の温度差はわずかで, およ光 $10^{\circ} \mathrm{Cであった} \mathrm{.}$

変形抵抗の測定は, 日本塑性加工学会推奨の同心円溝 
付き圧板を用いた拘束圧縮試験”により，試験温度に達 した試験片に約70\%まで加工を加えて行った .

前方押出し試験片は黑鉛を塗布した後，高周波加熱に より所定温度まで加熱された . 押出し金型の潤滑には黑 鉛を噴霧して用いた . 押出し用金型のインサートは超硬 で作られアプローチ角は120度とし減面率は30, 45, 60\% と変化させて, 絞り部の直径を20.9, 18.5, 15.8mmと変え ることにより対応した .オースフォーミングにより押出 しされた試験片は，加工後直接ミスト冷却された . 产の 後200 650 $60^{\circ} \mathrm{C}$ 温度範囲で1時間焼戻し処理を2回施し た. 弚して, 押出しされた試験片から切り出された各種 試験片 (シャルピー衝撃試験片は幅 $10 \mathrm{~mm} \times$ 高さ $5 \mathrm{~mm} \times$ 長さ $55 \mathrm{~mm}$ ，深さ $2 \mathrm{~mm}$ で半径 $1 \mathrm{~mm}$ のUノッ . 軟化抵抗 測定試験片は直径 $10 \mathrm{~mm}$ から $16 \mathrm{~mm} て ゙$ 長さ10 mm .) を用い て, 硬さ試験やシャルピ一衝撃試験, 光して焼戻し軟化 抵抗の測定を行った .なお，比較用として通常の焼入れ (1030 Cにて $30 \mathrm{~min}$ 加熱保持後油冷) - 焼戻し（200〜 $650^{\circ} \mathrm{C}$ にて1h保持後空冷を2回実施）を行った試験片も準 備した .

\section{3 実験結果}

Fig.4に600Cにおける変形抵抗を示す .オースフォー

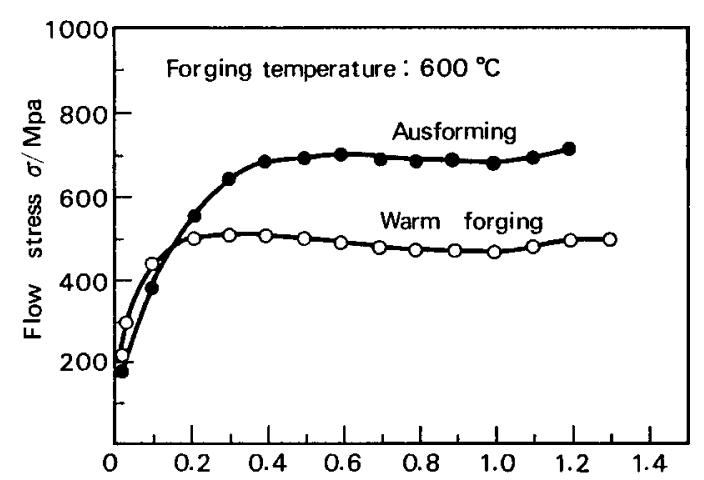

Fig. 4. Stress-strain curve of test steel.

ミング時の変形抵抗は, 通常の温間鍛造プロセスと比較 して40\%程高いものとなった .これは, 一般に, オース テナイト時の变形抵抗は, 未固溶析出物が多くない場合, 炭素固溶量で決まり, オースフォーミングは炭素がすべ て固溶した準安定オーステナイト状態での加工となるた め, 变形抵抗は上昇したものと考えられる.一方, 通常 の温間鍛造では, 球状化焼なまし組織のような球状化炭 化物と柔らかいフェライトの状態で加工されるため, 变 形抵抗は低くなる．ただし，圧延後の組織のようにマル テンサイトやベイナイトを多量に含むものを, 通常の温

間鍛造した場合，変形抵抗は著しく上昇し,オースフォ ーミングよりも更に高くなる

Fig.5に加工度を変化させてオースフォーミングを行 つたものと通常の焼入れを施したものの焼戻し曲線を示

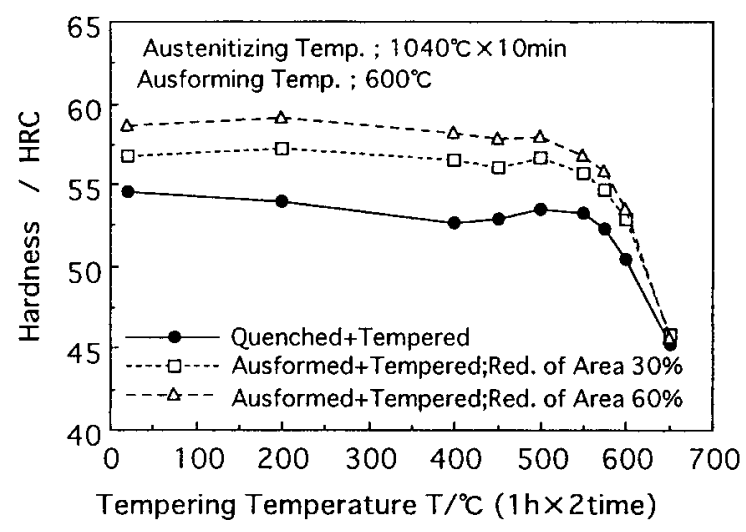

Fig. 5. Tempering curve of test steel.

す．オースフォーミングにより硬さは大幅に上昇してい る.これは，オースフォーミングされたものを焼戻した 場合，2次析出炭化物の析出開始温度は低温側に移り， また析出炭化物のサイズは加工度に比例して微細化され 硬さは増加10)することに起因する．また，焼戻し過程 で2次析出が始まる直前の硬さの落ち込みが不明瞭にな る傾向がみられる．この理由として，オースフォームを 行った時すでに二次硬化原因となる $\mathrm{Mo}_{2} \mathrm{C} \mathrm{VV}_{4} \mathrm{C}_{3}$ の析出 が起こり，焼入れ状態ですでに二次硬化を起こしたと同 じ効果 ${ }^{4), 11)}$ が生じていると言われている . Fig.6にオー スフォーミング (HA-process材) されたものと, 通常の

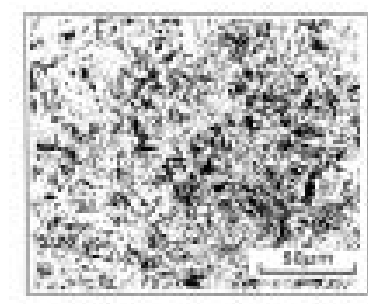

(a) As quenched

(1)

(1) QT-praces

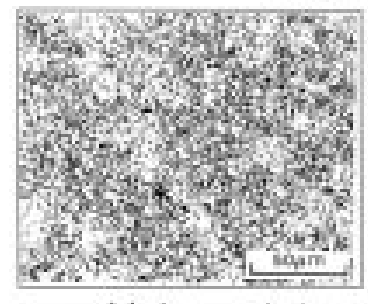

(a) hs evenched

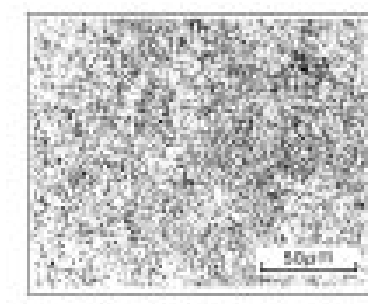

(b) after tempering

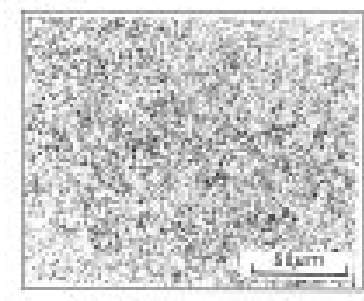

(b) After tenserine
(2) Mh-process

Fig. 6. Optical microstructures of test steel. 
焼入れおよび焼戻しされた材料 (QT-process材) の光学 顕微鏡組織を示す. 焼戻し後では不明瞭だが, 焼入れ後 の組織の違いよりオースフォーミングされたものは, マ ルテンサイト組織谷のものが微細化されていることが推 定できる.Fig.7に走査電子顕微鏡（SEM）により組織 を観察した結果を示す．オースフォーミング材のラスが
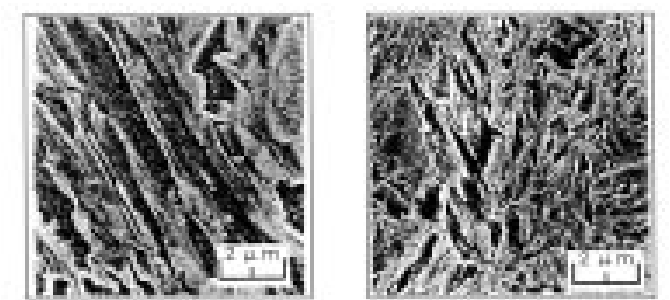

(a) OT-process (0R053. 9) (b) HA-prooess OHRC56. 2]

Fig. 7. Microstructures of test steel observed by SEM.

分断，微細化されていることが確認される。

Fig.8に硬さとシャルピー衝撃値の関係を示す . 一般 に, オースフォーミングの最大の特徵は, 強度が増加す るにも関わらず, 鞄性が維持あるいは向上することであ

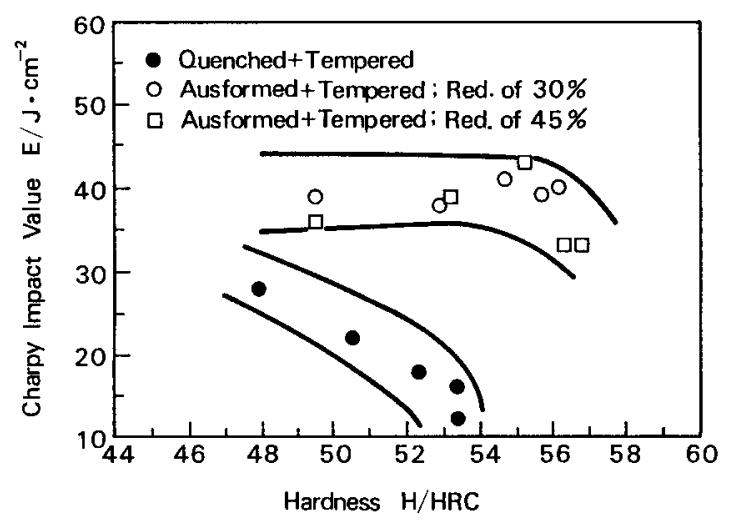

Fig. 8. Charpy impact value of test steel.

る. 今回得られた実験結果も同樣な傾向を示し，しかも 高硬度側での勒性については通常の焼入れ - 焼戻し材対 比約2倍以上の值となった . Fig.9に通常の焼入れ - 焼戻 し材 (QT-process材)，およびオースフォーミング後焼戻 しされた材料 (HA-process材 ; オースフォーミング後2 回焼戻し処理実施）のシャルピー衝撃試験後の破断面の SEM写真を示す．いずれも延性破面（ディンプル）と疑 へき開破面の混在する形態であるが，QT材に比較して HA材は硬さがHRCで約4ポイント高いにもかかわらず延 性破面の割合は増加し, 擬へき開破面の単位も減少して いる。

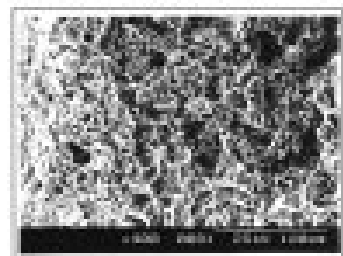

(a)

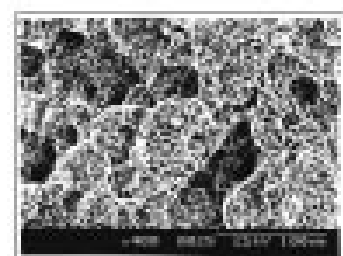

[a]

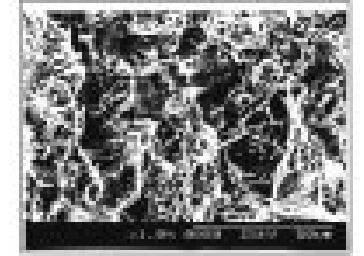

(b)

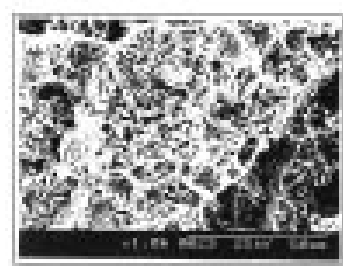

(b)
(2) Ha-precess 0Ac56. 2)

Fig. 9. Fracture surfaces of Charpy impact test.

Fig.10には，550Cにおいて長時間保持した時の軟化 抵抗を示す . オースフォーミングの特徵の1つとして， 軟化抵抗の向上年) が報告されているが,本鋼においても 同樣の結果が得られている .このような軟化抵抗の向上

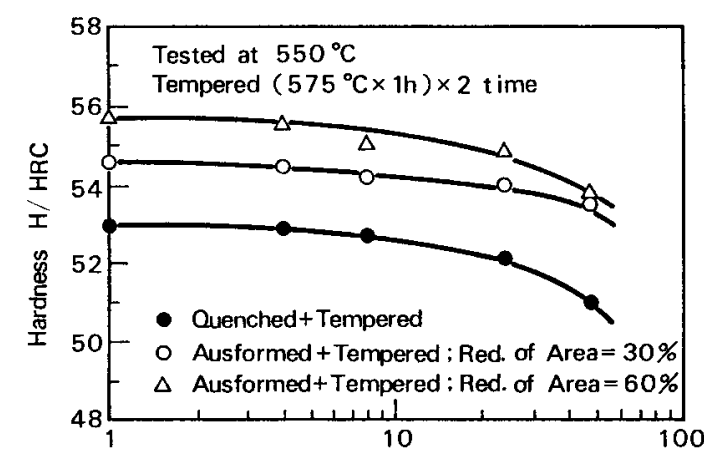

Fig. 10. Heat resistance of test steel.

は,単に加工硬化によって高強度化されたためではなく， 2次析出した炭化物の微細化がオースフォーミングの基 本的なメカニズムであるためと考えられる．

\section{[}

\section{HAプロセスの適用例 ]}

3.1 熱間鍛造用ベベルギヤ用ダイスへの適 用

塑性加工により金型を製造するホビング法とオースフ オーミングを組み合わせたHA - プロセスを，熱間鍛造 用ベベルギヤ用ダイス (モジュール4.375, 歯数10枚) に適用した . ホビング用ビレットには球状化焼鈍しされ たDH71の円柱片を用いた .ビレットは酸化防止のため 


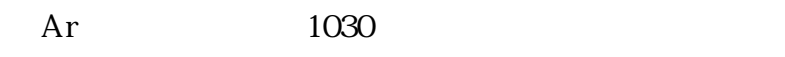
れ，衝風冷却によって $600^{\circ} \mathrm{Cに}$ に降温された後，鍛造加工 され, 弚の後水噴霧により冷却された，焼戻しは， $575^{\circ} \mathrm{C}$ で1時間加熱保持後空冷の処理を2回行った．また，

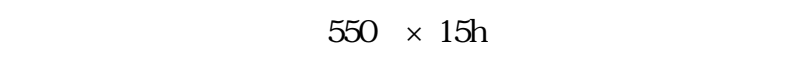

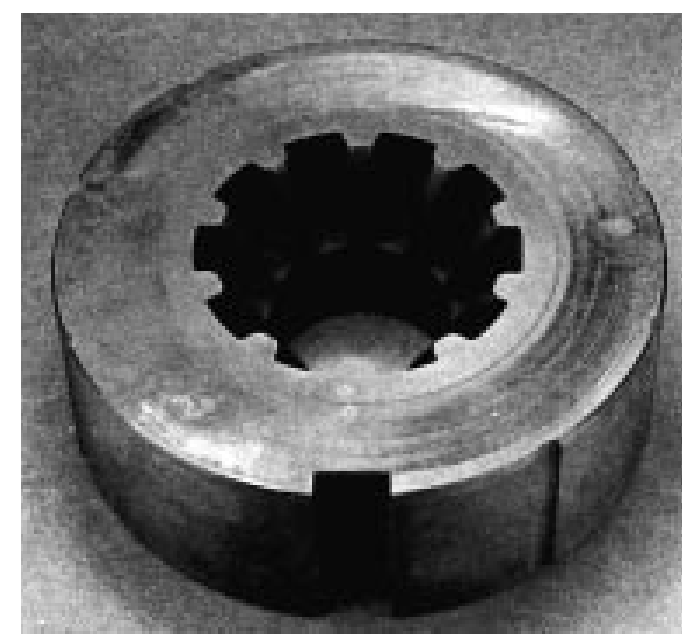

Fig. 11. Surface appearance of bevel gear.

った . Fig.11に完成したベベルギヤの外観を示す．

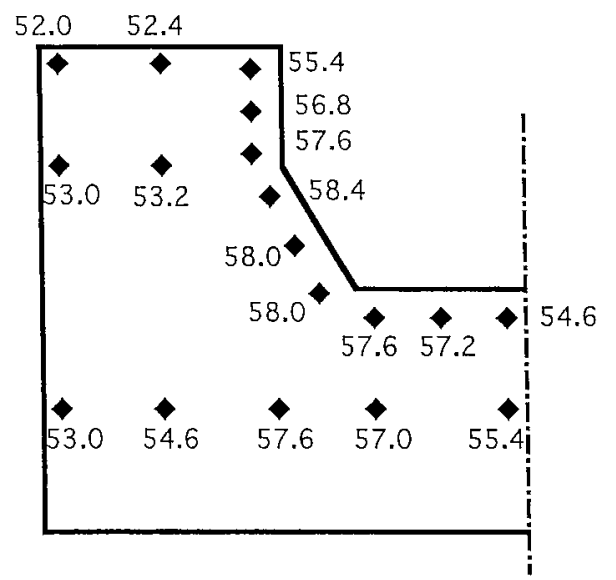

Fig. 12. Hardness distribution after tempering through HA

Fig.12にHA - プロセスによって製造された熱間鍛造 用ベベルギヤダイスの硬さ分布を示す . 歪みが十分に与 えられる歯部は，HRC58を超える硬さが得られる．前述 のようにHA - プロセスの場合 , このように高硬度状態 であっても勒性が十分に得られるため，ほぼ最高硬さが 得られるような条件で使用できる．

\section{2 実機寿命試験評価}

金型の寿命評価は，熱間横型多段成形機（ナショナル 製3-4)を使いSCr420材を $1200^{\circ} \mathrm{C} に$ 加熱し，生産速度 100rpmの条件でデフ・ピンを鍛造することで評価した .
通常の焼入れ - 焼戻し処理によって製造された金型 (HRC 48-50) の寿命は10851ショットであるのに対し， HA -プロセスによって製造された金型は，17156ショッ トの寿命が得られた . 寿命の主因は , どちらの金型も

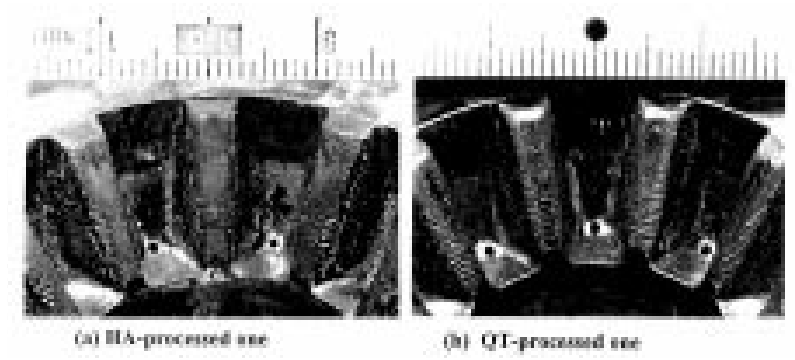

Fig.13. Surface appearances of bevel gear after forging.

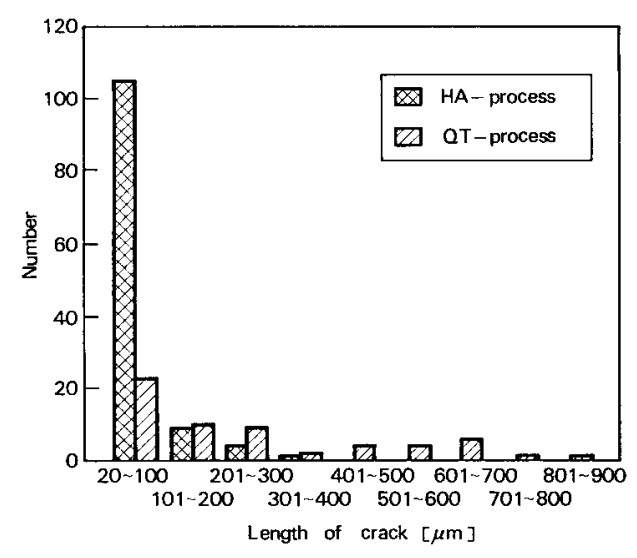

Fig. 14. Crack length distribution after forging.

Fig.13に示すようなヒートクラックである . Fig.14に鍛 造後の両金型のヒートクラックの深さと, クラック発生 数の分布を示す. 通常の焼入れ - 焼戻し処理によって製 造された金型は多くの大きなクラックが存在しており， ダメージの度合いが大きい，一方，HA -プロセスによ って製造された金型はヒートクラックのサイズが小さ

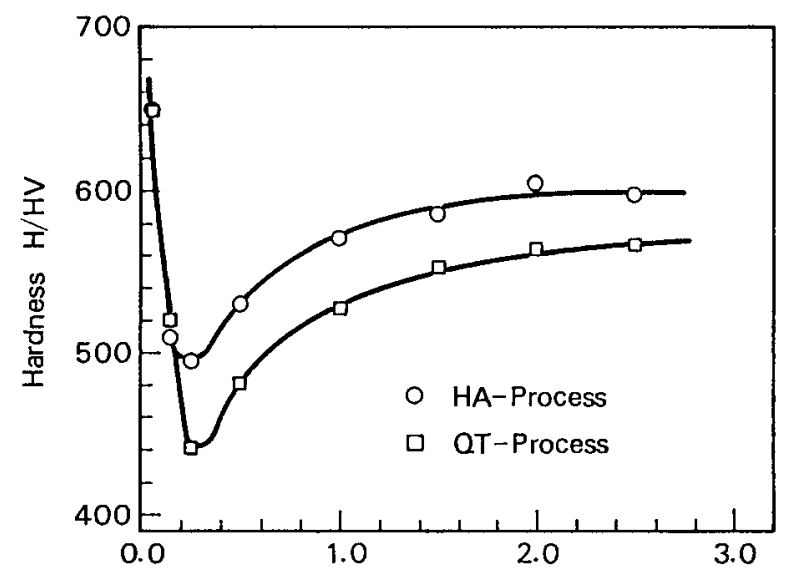

Fig. 15. Hardness distribution of tooth after forging. 
く, ダメージの度合いも小さい，Fig.15は，鍛造後の硬 さ分布を歯の長さ方向の中央位置で歯先から歯元に向か って測定した結果である . 表面層は窒化の影響をうけて 高い硬さを保っているが, 深くなるにつれて加工中の熱 による焼庆しの影響をうけて硬さは大きく低下する．し かし, 初期硬さの影響によりHA - プロセス材の方が QT -プロセス材に比して高い硬さを維持している．

このように，HA -プロセスによって製造された金型 は，ほぼピーク硬さの状態で使用されているにも関わら ず大きな割れは一切認められず, 金型の高寿命化に対し て非常に有効な手段であることが確認された .

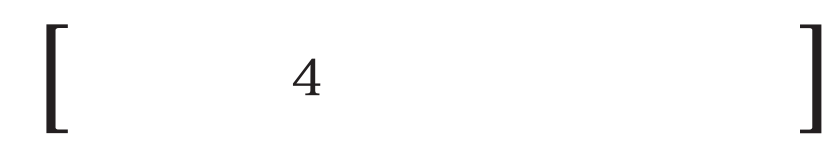

オースフォーミングとホビングを組み合わせて高強 度・高勒性の金型を塑性加工で製造するHA - プロセス を開発し，0.4C-1Mn-3Cr-2Mo-1V系熱間鍛造用材料（大 同鋼種名DH71) に対して適用した。弚の結果, 以下の ことが明らかとなった .

（1）前方押出しによる基礎的な試験より，本鋼種にオー スフォーミングを適用することにより鞄性を約2倍に向 上させるとともに, 最大硬さが通常の焼入れ - 焼戻しで 得られる硬さよりHRCで5ポイント高くなる事が分かっ た。

（2）強度と勒性が向上する理由として組織の微細化が考 えられる。
（3）ホビングとオースフォーミングを組み合わせること により熱間鍛造用ベベルギヤ用金型を製作し，熱間横型 高速多段成形機にて実機試験を行ったところ金型寿命は 大幅に向上した .この理由として , オースフォーミング をホビングに適用したHA - プロセスでは, 勒性向上の ため最高硬さ状態での使用が可能となり，耐摩耗，耐七 ートクラック性が向上したためと考えられる。

(文献)

1) H. Hoischen: Ind. - A nz., 89 (1967), 1255

2) E. Doege: 9. Umformtechnisches Kolloquium, (Hannover 1978), 155

3）田村今男:鉄と鋼, 2(1966), 140

4) 佐藤昭治, 渡辺 敏: 法政大学工学部研究集報, 21 (1985), 77

5) 牧 正志,田村今男:熱処理, 26(1986), 353

6) C. N. Elias: Material Science and Technology, 8(1992), 785

7) 大森宮次郎, 田中忠賢, 斉藤 勉, 田中大麗:熱処理, 20(1992), 99

8) 大森宮次郎:熱処理, 35(1995), 2579

9) 戶澤康壽: 塑性と加工, 30(1989), 1131

10) 田村今男:鉄鋼材料強度学(1969), 195 , [日刊工業新 聞社]

11) 田村今男, 吉村, 茨木, 多賀谷:日本金属学会誌, 23 (1964), 433 